\title{
Pengaruh Substitusi Tepung Kulit Pisang Kepok (Musa Paradisiaca L) terhadap Kadar Serat dan Daya Terima Cookies
}

\author{
The Effect Subtitation Of Kepok Banana (Musa Paradisiaca L) Skin To Fiber Content \\ And Accept Power Of The Cookies
}

\section{MARIATUL KIPTIAH ${ }^{1 *}$, NINA HAIRIYAH ${ }^{1}$, AYU NURMALASARI ${ }^{1}$}

${ }^{1}$ Jurusan Teknologi Industri Pertanian, Politeknik Negeri Tanah Laut, Jl. A. Yani, km.6, Desa Panggung, Kec. Pelaihari.Kab. Tanah Laut, Kalimantan Selatan 70815, Indonesia *Email: Mariatul@politala.ac.id

\begin{abstract}
Carbohydrate content in banana skin of $18.50 \%$, banana peel potency as a source of starch for the manufacture of banana peel flour. The banana peel flour can be utilized as a substitute agent for making cookies to increase the fiber value. Measuring the yield of banana peel flour produced in the cookies process using the sun drying method, analyzing the best formulation composition of banana peel flour substitution on cookies and analyzing the level of panelist acceptance of the resulting cookie products. The design of the research was a complete randomized design with 4 substitution treatments of wheat flour and banana peel flour which were Al (100\%: 0), A2 (75\%: 25\%), A3 (70\%: 30\%), A4 (65\%:35\%) and A5 (50\%: 50\%) as well as water content and fiber content. Parameters to be estimate were moisture/water contain, fiber content, organoleptic test (flavor, aroma, texture and color). The data obtained were tested by ANOVA and continued test of DMRT to determine the effect of treatment on each treatment of cookies based on the results of the characteristics of the best banana peel banana flour (A2) 75\% and 25\% kepok kepok banana fiber with $15.34 \%$ treat (A4) $65 \%$ and banana peel flour $35 \%$ yielded 25,27\%. Based on the results of acceptance test, it is recommended to use $25 \%$ banana peel flour.
\end{abstract}

Keywords: ANOVA, Banana skin flour, Cookies, DMRT, Organoleptic Test

\begin{abstract}
ABSTRAK
Kulit pisang berpotensi sebagai sumber pati untuk pembuatan tepung karena mengandung karbohidrat sebesar $18,50 \%$. Tepung kulit pisang kepok dapat dimanfaatkan sebagai bahan pensubtitusi pembuatan cookies untuk meningkatkan nilai serat. Penelitian ini dilakukan untuk mengukur rendemen tepung kulit pisang yang dihasilkan pada proses pembuatan cookies menggunakan metode pengeringan sinar matahari, menganalisis perbandingan formulasi terbaik substitusi tepung kulit pisang kepok pada cookies, dan menganalisis tingkat penerimaan panelis terhadap produk cookies yang dihasilkan. Rancangan penelitian yang digunakan adalah rancangan acak lengkap dengan 4 perlakuan substitusi tepung terigu dan tepung kulit pisang kepok yaitu A1 (100\%:0), A2 (75\%: 25 $\%)$, A3 (70\%: 30\%), A4 (65\%: 35\%) dan A5 (50\%: 50\%), kemudian dilanjutkan dengan analisis kadar air dan kadar serat. Pada masing-masing perlakukan dianalisis uji organoleptik (rasa, aroma, tekstur dan warna). Data yang diperoleh diuji ANOVA dan uji lanjutan DMRT untuk mengetahui pengaruh perlakukan pada masing-masing perlakukan cookies. Hasil penelitian menunjukkan bahwa karakteristik tepung kulit pisang kepok
\end{abstract}


perlakukan terbaik yaitu tepung terigu 75\% dan tepung kulit pisang kepok $25 \%$ dengan kadar air 2,13\% serta kadar serat 15,34\%. Berdasarkan hasil uji daya terima, penggunaan tepung kulit pisang kapok sebesar 75\% tepung terigu 25\% tepung kulit pisang kepok lebih disukai oleh panelis.

Kata kunci: Tepung kulit pisang kepok, Cookies, Uji Organoleptik, ANOVA, DMRT

\section{PENDAHULUAN}

Tanaman pisang berasal dari daerah tropis yang beriklim basah dan dapat tumbuh baik di dataran rendah sampai dataran tinggi 1.000 - 3.000 mdpl (Hartono dkk., 2013). Buah pisang memiliki jenis yang beragam, salah satu pisang yang sering digunakan oleh para pedagang dalam menjual jenis jajanan seperti pisang goreng, molen goreng, pisang kipas adalah jenis pisang kepok.

Kulit pisang kepok jarang dimanfaatkan sebagai bahan makanan oleh masyarakat setempat dan hanya dimanfaatkan sebagai pakan ternak dan hanya dibuang begitu saja, padahal kandungan karbohidrat dalam kulit pisang tinggi. Secara umum kandungan gizi kulit pisang sangat banyak terdiri dari mineral, vitamin, karbohidrat, protein, lemak dan lain-lain. Menurut Hikmatun (2014) Kandungan karbohidat pada kulit pisang sebesar $18,50 \%$, sehingga kulit pisang berpotensi sebagai sumber pati untuk pembuatan tepung kulit pisang.

Tepung dari kulit pisang ini berpotensi digunakan untuk mengurangi jumlah tepung terigu yang biasa dipakai dalam pembuatan cookies. Bahan utama pembuatan cookies adalah tepung terigu yang selama ini cookies biasa dikonsumsi hanya mengandung zat gizi makro saja dan rendah serat. Penelitian Kisnawaty dan Kurnia, (2017) ternyata bahan pembuatan kue lain yang bermanfaat sebagai olahan kue yaitu menggunakan biji nangka sebagai subtitusi pembuatan cookies. Hal ini dilakukan sebagai dasar penelitian penambahan tepung kulit pisang pada cookies dalam upaya memperbaiki kandungan gizi terutama kandungan serat pada cookies.

Menurut penelitian Wakano, dkk., (2016) kulit pisang dapat dimanfaatkan untuk membuat keripik sebagai sumber makanan yang berkalsium tinggi guna memenuhi kebutuhan gizi keluarga. Hasil penelitian menunjukkan bahwa keripik kulit pisang mengandung karbohidrat sebesar 42,5\%, Protein 1,00\%, Lemak 1,5\%, Kalsium 7,5\%, Fosfor 9,5\%, Besi 1,2\%. Vitamin B 0,9\%Vitamin C 1,75\%. Sedangkan untuk donat karbohidrat $52,9 \%$, protein $1,32 \%$, lemak $2,3 \%$, kalsium $10 \%$, fosfor $11,5 \%$, Besi $2.1 \%$, Vtamin B1.5\%,dan vitamin C 2.59\%. 


\section{METODE PENELITIAN}

\section{Bahan}

Bahan yang digunakan dalam penelitian ini adalah kulit pisang kepok, air, tepung terigu, gula halus, margarin, kuning telur, garam, butter dan susu bubuk. Bahan yang digunakan untuk analisis kadar serat adalah $\mathrm{H}_{2} \mathrm{SO}_{4}, \mathrm{NaOH}, \mathrm{K}_{2} \mathrm{SO}_{4}$ dan alkohol $95 \%$ teknis.

\section{Alat}

Alat yang digunakan dalam penelitian ini adalah neraca analitik, baskom, blender, ayakan, panci kukusan, mixer, cetakan cookies, loyang oven, sendok, piring kecil, kompor gas, batang pengaduk, erlenmeyer, desikator, gelas ukur, labu ukur, pinset, pipet tetes, spatula, cawan porselin dan kertas saring.

\section{Pembuatan tepung kulit pisang kepok}

Pembuatan tepung kulit pisang kepok dimodifikasi dari Kahara (2016) dalamYudha dan Joni (2015) kulit pisang kepok sebanyak 1,5 kg disortasi untuk memilih kulit yang terbaik kemudian dikupas kulit luar pisang dan ambil bagian dalam kulit yang bewarna putih setelah itu dicuci dan dipotong-potong kemudian dikukus, kemudian dilakukan pengeringan dengan menggunakan sinar matahari dengan suhu kira-kira $\pm 0^{\circ} \mathrm{C}$ dengan waktu pengeringan selama 2 hari ( \pm 12 jam), selanjutnya dilakukan penggilingan dan pengayakan menggunakan ayakan 80 mesh sehingga diperoleh tepung kulit pisang kepok.

\section{Analisis Rendemen}

Rendemen adalah perbandingan jumlah (kuantitas) bahan utama yang dihasilkan dari tanaman. Rendemen menggunakan satuan persen (\%). Semakin tinggi nilai rendemen yang dihasilkan menandakan nilai bahan utama yang dihasilkan semakin banyak. Kualitas bahan yang dihasilkan biasanya berbanding terbalik dengan jumlah rendemen yang dihasilkan. Semakin tinggi nilai rendemen yang dihasilkan maka semakin rendah mutu yang di dapatkan (Dion, 2017). Rumusan perhitungan rendemen disajikan pada rumus berikut :

Rendemen $=\frac{B}{A} \times 100 \%$ 
Keterangan :

$\mathrm{B}=$ berat akhir kulit pisang yang sudah dikeringkan dan dijadikan tepung

$\mathrm{A}=$ berat awal kulit pisang sebelum dikeringkan

\section{Pembuatan Cookies Tepung Kulit Pisang Kepok}

Proses pembuatan cookies tepung kulit pisang yaitu bahan ditimbang menggunakan neraca analitik dengan perlakuaan A1 0\%, A2 25\%, A3 30\% A4 35\% dan A5 50\%. Bahan-bahan dalam pembuatan cookies yaitu tepung kulit pisang kepok, tepung terigu perlakuan A1 100\%, A2 75\%, A3 70\%, A4 65\% dan A5 50\%, gula halus 80 gram, margarin 50 gram, butter 25 gram, 1 kuning telur, garam secukupnya susu bubuk 75 gram dan Chocochip. Bahan-bahan seperti kuning telur, gula halus dan margarin dikocok dengan menggunakan mixer selama 10 menit, selanjutnya campur tepung kulit pisang kepok dan tepung terigu menggunakan mixer dan letakkan adonan dalam tuangan kemudian adonan dipanggang dengan suhu $130^{\circ} \mathrm{C}$ selama 35 menit.

\section{Uji Kadar Air}

Kadar air berkaitan dengan kualitas dan stabilitas bahan, karena kadar air sangat berpengaruh besar dalam pengujian setiap bahan pangan dalam kehidupan sehari-hari (Hombing, 2016). Prosedur Uji kadar air pada pembuatan cookies yaitu uji kadar air dilakukan dengan cara menimbang sampel cookies sebanyak 1-2 gram dan dimasukan kedalam cawan porselin yang telah dioven selama 15 menit dan ditimbang berat cawan kosong, setelah itu cawan dan sampel dimasukkan kedalam oven dengan suhu $100-105^{\circ} \mathrm{C}$ selama 3 jam kemudian setelah dioven didinginkan didalam desikator selama 15 menit dan ditimbang berat akhir sampel menggunkaan neraca analitik sampai berat konstan. Menentukan kadar air menurut pendapat Singh et.al (2008) menjelaskan bahwa kandungan air dalam suatu bahan yang semakin sedikit menjadikan tekstur menjadi semakin kering sehingga akan mengakibatkan cookies lebih mudah patah. Rumus perhitungan kadar air adalah sebagai berikut:

$$
\text { Kadar air }(\%)=\frac{\text { Berat awal sampel }- \text { Berat akhir sampel }}{\text { Berat awal sampel }} \times 100 \%
$$

\section{Uji kadar serat}

Serat merupakan salah satu bahan pangan yang terbentuk dari dinding sel tanaman keras sehingga mempengaruhi kerenyahan dari cookies (Andarwulan et.al 2011). Mengetahui analisis kadar serat dilakukan dengan menimbang 2 gram tepung kulit pisang kepok dimasukan kedalam Erlenmeyer 250 ditambahkan $200 \mathrm{ml} \mathrm{H}_{2} \mathrm{SO}_{4} 1,25 \%$, lalu 


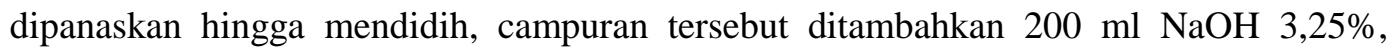
kemudian dipanaskan kembali selama 30 menit. Campuran dalam keadaan panas disaring dengan corong yang telah berisi kertas saring yang telah diketahui bobotnya. Endapan yang terdapat pada kertas saring dicuci dengan $\mathrm{K}_{2} \mathrm{SO}_{4}$, air panas, dan etanol $96 \%$, kemudian kertas saring beserta isinya diangkat dan ditimbang. Kertas saring beserta isinya selanjutnya dikeringkan dalam oven pada suhu $105^{\circ} \mathrm{C}$ selama 1 jam didinginkan dan ditimbang. Serat kasar dihitung dengan rumus:

Kadar Serat $(\%)=$ Berat sampel + residu - Berat kertas saring kosong $\times 100 \%$

Berat sampel

\section{Uji Tingkat Kesukaan (Uji Hedonik)}

Uji hedonik pada produk cookies berbasis tepung kulit pisang ini untuk mengetahui pengaruh penambahan tepung kulit pisang pada produk cookies dan untuk mendapatkan formulasi cookies terbaik berdasarkan daya terima panelis, uji yang dilakukan yaitu dengan mencari 20 orang panelis untuk mengisi score sheet uji hedonik untuk hasil yang didapatkan dari uji hedonik tersebut kemudian dirata-ratakan untuk menentukan perbandingan terbaik berdasarakan nilai rata-rata tertinggi.

Berdasarkan pendapat Setyaningsih dkk., (2011) menyatakan bahwa uji hedonik merupakan pernyataan tentang baik atau buruknya mutu suatu produk dengan produk pesaing. Uji ini dapat diaplikasikan pada saat pengembangan produk atau pembandingan produk pada pengukuran untuk uji hedonik cookies berbasis tepung kulit pisang meliputi rasa, aroma, warna dan tekstur penilaian tersebut dengan skala penilaian diantaranya adalah 1 sangat tidak suka, 2 tidak suka, 3 agak suka, 4 suka dan yang terakhir yaitu skala 5 sangat suka.

\section{HASIL DAN PEMBAHASAN}

\section{Rendemen dan kadar air Tepung Kulit Pisang Kepok}

Pada proses pengolahan Tepung Kulit Pisang Kepok yang dilakukan dengan menggunakan metode pengeringan yaitu dengan sinar matahari dengan suhu kira-kira $40^{\circ} \mathrm{C}$ dengan waktu pengeringan selama 2 hari $( \pm 12$ jam$)$, didapatkan hasil perhitungan rendemen sebesar $14,68 \%$ dengan kadar air sebesar 7,25\%.

Hasil penelitian menunjukkan bahwa semakin lama waktu pengeringan, akan menghasilkan proses pengeringan yang optimal karena kandungan air yang menguap 
akan semakin besar sehingga rendemen yang dihasilkan semakin sedikit. Hal ini sesuai dengan penelitian Martunis (2012) yang mengatakan bahwa perbedaan tinggi dan rendahnya rendemen dalam suatu bahan pangan sangat dipengaruhi oleh kandungan air suatu bahan pangan.

\section{Kadar serat dan Kadar air Cookies}

Pengujian karakteristik Cookies Substitusi Tepung Kulit Pisang Kepok dengan lima formulasi yang meliputi kadar air dan uji kadar serat disajikan pada Tabel 2. Pada pengujian kadar air tiap sampel cookies yang dihasilkan dari lima formulasi yaitu $100 \%$ tepung terigu, $75 \%$ tepung terigu dan $25 \%$ tepung kulit pisang kepok, $70 \%$ tepung terigu dan 30\% tepung kulit pisang kepok, 65\% tepung terigu dan 35\% tepung kulit pisang kepok dan masing-masing 50\% tepung terigu juga tepung kulit pisang kepok, sehingga hasil kadar air yang tertinggi ditunjukan pada formulasi 50\% tepung terigu dan tepung kulit pisang kepok sebesar 5,60\%. Peningkatan kadar air pada bahan pangan dipengaruhi oleh substitusi tepung kulit pisang lebih tinggi yaitu 50\% sedangkan untuk kadar air yang terendah yaitu tepung terigu $65 \%$ pada substitusi tepung kulit pisang $35 \%$ yaitu $1,48 \%$ sedangkan tanpa penambahan tepung kulit pisang hasil yang didapatkan yaitu 2,61\% dapat diketahui bahwa semakin banyak penambahan tepung kulit pisang maka kadar air yang dihasilkan cukup tinggi sedangkan untuk penambahan tepung kulit pisang dengan jumlah yang sedang mendapatkan hasil rata-rata kadar air 2,13-2,64\%. Menurut Andarwulan et.al (2011) menyatakan bahwa semakin tinggi subtitusi tepung pisang menyebabkan adanya kerenyahan pada cookies karena kadar air yang terkandung pada tepung pisang menjadi lebih rendah dibandingkan dengan tepung terigu.

Berdasarkan uji kadar air dari semua perlakukan cookies, kadar air yang didapatkan berkisar antara 1,48\%-5,60\%. Berdasarkan standar mutu kadar air cookies menurut SNI 01-2973-1992 maksimum 5\% sehingga kadar air pada cookies yang dihasilkan memenuhi standar mutu cookies. Kadar air cookies dipengaruhi oleh bahanbahan yang digunakan pada pembuatan serta dipengaruhi oleh suhu saat pemasakan ataupun penyimpanan produk.

Menurut SNI 01-2973-1992 tentang syarat mutu cookies menyatakan bahwa kadar serat maksimal adalah $0,5 \%$ (db). Hasil penelitian menunjukan kadar serat dari semua perlakukan lebih dari 0,5\% dengan demikian kadar serat cookies hasil penelitian belum memenuhi syarat mutu cookies yang ditetapkan oleh standar SNI. 
Tabel 2. Hasil Pengujian Karakteristik Cookies Substitusi Tepung Kulit Pisang Kepok

\begin{tabular}{|c|c|c|c|}
\hline Perlakuan & Gambar & $\begin{array}{c}\text { Rata-rata } \\
\text { Kadar Air } \\
(\%)\end{array}$ & $\begin{array}{c}\text { Rata-rata } \\
\text { Kadar Serat } \\
(\%)\end{array}$ \\
\hline A1 & & 2,61 & 16,67 \\
\hline A2 & & 2,13 & 15,34 \\
\hline A3 & & 2,64 & 27,79 \\
\hline A4 & & 1,48 & 25,27 \\
\hline A5 & & 5,60 & 69,65 \\
\hline
\end{tabular}

Keterangan :

A1 : 100\% Tepung Terigu dan 0\%Tepung Kulit Pisang Kepok

A2 : $75 \%$ Tepung Terigu dan 25\% Tepung Kulit Pisang Kepok

A3 : 70\% Tepung Terigu dan 30\% Tepung Kulit Pisang Kepok

A4 : $65 \%$ Tepung Terigu dan 35\% Tepung Kulit Pisang Kepok

A5 : 50\% Tepung Terigu dan 50\% Tepung Kulit Pisang Kepok

Serat mampu menyerap air dan mengikat glukosa sehingga mengurangi ketersediaan glukosa dan mampu mencegah kenaikan glukosa darah serta menjadikannya tetap terkontrol. Semakin tinggi serat yang terkandung maka semakin baik untuk pencernaan. Serat dalam saluran pencernaan dapat mengikat garam empedu dan 
mengeluarkannya bersama feses sehingga dapat menurunkan sampai 5\% kadar kolesterol dalam darah (Santoso, 2011).

\section{Daya Terima}

Berdasarkan hasil analisis statistik terhadap daya penerimaan masyarakat terhadap warna, aroma, rasa, tekstur pada cookies dapat dilihat pada Tabel 3.

Tabel 3. Hasil Uji Duncan/DMRT pengaruh tepung kulit pisang kepok pada uji hedonik cookies

\begin{tabular}{lllllllll}
\hline Perlakuan & \multicolumn{9}{c}{ Uji hedonic } \\
\cline { 2 - 8 } & Rasa & Aroma & Tekstur & Warna & Rasa & Aroma & Tekstur & Warna \\
A1 & $4,30^{\mathrm{a}}$ & $4,35^{\mathrm{a}}$ & $4,30^{\mathrm{a}}$ & $4,25^{\mathrm{a}}$ & $4,30^{\mathrm{a}}$ & $4,35^{\mathrm{a}}$ & $4,30^{\mathrm{a}}$ & $4,25^{\mathrm{a}}$ \\
A2 & $3,80^{\mathrm{b}}$ & $3,45^{\mathrm{b}}$ & $3,70^{\mathrm{b}}$ & $3,65^{\mathrm{b}}$ & $3,80^{\mathrm{b}}$ & $3,45^{\mathrm{b}}$ & $3,70^{\mathrm{b}}$ & $3,65^{\mathrm{b}}$ \\
A3 & $3,55^{\mathrm{b}}$ & $3,55^{\mathrm{b}}$ & $3,55^{\mathrm{b}}$ & $3,60^{\mathrm{b}}$ & $3,55^{\mathrm{b}}$ & $3,55^{\mathrm{b}}$ & $3,55^{\mathrm{b}}$ & $3,60^{\mathrm{b}}$ \\
A4 & $3,45^{\mathrm{b}}$ & $3,30^{\mathrm{b}}$ & $3,70^{\mathrm{b}}$ & $3,75^{\mathrm{b}}$ & $3,45^{\mathrm{b}}$ & $3,30^{\mathrm{b}}$ & $3,70^{\mathrm{b}}$ & $3,75^{\mathrm{b}}$ \\
A5 & $3,70^{\mathrm{b}}$ & $3,60^{\mathrm{b}}$ & $3,65^{\mathrm{b}}$ & $3,75^{\mathrm{b}}$ & $3,70^{\mathrm{b}}$ & $3,60^{\mathrm{b}}$ & $3,65^{\mathrm{b}}$ & $3,75^{\mathrm{b}}$ \\
\hline
\end{tabular}

Keterangan : Angka yang diikuti pada huruf yang sama pada kolom yang sama berarti berbeda tidak nyata pada uji DMRT 5\% dan $1 \%$

Skor tertinggi uji tingkat kesukaan panelis pada rasa yaitu pada substitusi tepung kulit pisang $0 \%$ yaitu sebesar 4,3, selanjutnya dilakukan analisis data tingkat kesukaan panelis terhadap rasa uji Analisis Of Varians (ANOVA) menunjukan bahwa berpengaruh nyata kemudian dilakukan uji lanjutan DMRT untuk melihat perbedaan dari tiap perlakukan formulasi terhadap tingkat kesukaan panelis pada rasa cookies. Hasil dari uji DMRT pada setiap formulasi pembuatan cookies terdiri pada tingkat 5\% dan $1 \%$ dapat diketahui bahwa antara perlakuan $75 \%$ tepung terigu dan $25 \%$ tepung kulit pisang kepok, $70 \%$ tepung terigu dan 30\% tepung kulit pisang kepok, $65 \%$ tepung terigu dan $35 \%$ tepung kulit pisang kepok dan masing-masing 50\% tepung terigu juga tepung kulit pisang kepok, sehingga hasil kadar air yang tertinggi ditunjukan pada formulasi 50\% tepung terigu dan tepung kulit pisang kepok sebesar 5,60\%. Sedangkan untuk sampel 100\% tepung terigu dengan yang lain berbeda nyata dengan keempat perlakuan lainnya terhadap tingkat kesukaan yang dihasilkan terhadap rasa cookies substitusi tepung kulit pisang kepok yang memberikan rasa sepat dari pembuatan cookies. Menurut Kahara (2016), kandungan tanin pada kulit pisang mentah sebesar 7,36\% dan setelah masak turun menjadi $1,99 \%$. Senyawa tanin adalah senyawa astringent yang memiliki rasa sepat (pahit).

Uji Analisis Of Varians (ANOVA) untuk tingkat kesukaan panelis terhadap aroma dihasilkan bahwa aroma terhadap cookies berpengaruh nyata kemudian dilakukan 
uji lanjutan DMRT untuk melihat perbedaan dari tiap perlakukan formulasi terhadap tingkat kesukaan panelis pada aroma cookies. Hasil dari uji DMRT tingkat 5\% dan 1\% dapat diketahui bahwa aroma pada perlakuakn $100 \%$ tepung terigu atau kontrol berbeda nyata dengan tepung terigu dan tepung kulit pisang kapok masing-masing 50\%, 65\% tepung terigu dan 35\% tepung kulit pisang kepok, $70 \%$ tepung terigu dan 30\% tepung kulit pisang kepok, $75 \%$ tepung terigu dan 25\% tepung kulit pisang kepok. Hal itu disebabkan oleh adanya penambahan kulit pisang kepok. Menurut Azizah (2012), aroma pada cookies juga dapat disebabkan reaksi Maillard karena kandungan karbohidrat produk cookies yang makin tinggi dan adanya komponen protein dalam bahan penyusunnya sehingga berfungsi untuk menghasilkan flavor dan aroma.

Berdasarkan uji Analisis of Varians (ANOVA) untuk perlakuan yang berpengaruh nyata kemudian dilakukan uji lanjutan DMRT untuk melihat perbedaan dari tiap perlakukan formulasi terhadap tingkat kesukaan panelis pada tekstur cookies. Hasil dari uji DMRT tingkat 5\% dan 1\% dapat disimpulkan bahwa untuk perlakukan tepung terigu dan tepung kulit pisang kepok masing-masing 50\%, 75\% tepung terigu dan $25 \%$ tepung kulit pisang kepok, $70 \%$ tepung terigu dan 30\% tepung kulit pisang kepok dan $65 \%$ tepung terigu dan 35\% tepung kulit pisang kepok pada sampel tersebut berbeda nyata pada perlakuan $100 \%$ tepung terigu dan tepung kulit pisang kepok. Menurut Subandoro dkk (2013), tepung kulit pisang tidak mengandung gluten yang berperan terhadap pembentukan tekstur cookies yang baik, sedangkan tepung terigu mengandung protein gluten, sehingga pori-pori yang terbentuk dalam adonan juga kecil - kecil yang mengakibatkan adonan tidak mengembang dengan baik, maka setelah pembakaran selesai akan menghasilkan produk yang keras.

Hasil uji DMRT (Duncan Multiple Range Test) tingkat 5\% dan 1\% pada parameter warna menunjukan bahwa perlakuan $100 \%$ tepung terigu dan tepung kulit pisang kepok berbeda nyata dengan sampel $75 \%$ tepung terigu dan $25 \%$ tepung kulit pisang kepok , 70\% tepung terigu dan 30\% tepung kulit pisang kepok, $65 \%$ tepung terigu dan $35 \%$ tepung kulit pisang kepok dan tepung terigu juga tepung kulit pisang kepok masing-masing 50\%. Cookies yang disubstitusi dengan tepung kulit pisang berwarna kecoklatan.Warna coklat ini berasal dari komponen polifenol dan tannin yang terkandung dalam kulit pisang.Hal ini dikarenakan kulit pisang kepok mudah mengalami reaksi browning enzimatik dimana enzim polyphenol oksidase bereaksi dengan senyawa fenolik yang menghasilkan zat kuinon, zat ini kemudian mengalami polimerasi oksidatif non 
enzimatik yang menghasilkan warna kecoklatan pada tepung kulit pisang kepok (Ermawati dkk, 2016).

\section{KESIMPULAN}

Berdasarkan hasil penelitian pengaruh substitusi tepung kulit pisang kepok terhadap kadar serat dan daya terima cookies disimpulkan bahwa rendemen tepung kulit pisang yang dihasilkan pada proses pembuatan dengan menggunakan metode pengeringan sinar matahari sebesar $14,68 \%$, dengan kadar air $7,25 \%$, formulasi terbaik subtitusi pisang kepok pada cookies diperoleh hasil tepung terigu $75 \%$ dan tepung kulit pisang kepok 25\% dengan kadar serat 15,34\% maka nilai pada rasa 3,80, aroma 3,45, tekstur 3,70 dan warna 3,65. Formulasi ini menunjukkan cookies yang disubstitusi tepung kulit pisang, persentase substitusi tepung kulit pisang kepok $25 \%$ lebih disukai oleh panelis dan tidak terdapat perbedaan yang nyata dengan persentase substitusi $30 \%, 35 \%$ dan $50 \%$.

\section{DAFTAR PUSTAKA}

Andarwulan, N. Kusnandar, F., Herawati, D. 2011. 'Analisis Pangan'. PT. Dian Rakyat, Jakarta

Azizah, H. N. 2012. 'Pengaruh Penggunaan Tepung Tempe sebagai Bahan Pensubstitusi Daging Sapi Terhadap Komposisi Proksimat dan Daya Terima Sosis'. Skripsi. Surakarta: Universitas Muhammadiyah Surakarta.

Dion, S. 2017. 'Ekstrak dan Ekstraksi'. http://dionsimon 1997. Blogspot.com/201 7/03/Diakses pada tanggal 30 Mei 2018 pukul 10.25 Wita.

Ermawati, W.O., Wahyuni, S., Rejeki, S. 2016. 'Kajian Pemanfaatan Limbah Kulit Pisang Raja (Musa paradisiaca var Raja) dalam Pembuatan Es Krim', Jurnal Sains dan Teknologi Pangan Vol. 1 No. 1, p.67-72, Th 2016.

Hartono,A., Pramudyo, J.H.B. 2013. 'Pelatihan Pemanfaatan Limbah Kulit Pisang Sebagai Bahan Dasar Pembuatan Kerupuk'. Jurusan Manajemen Fakultas Ekonomi Universitas Islam Indonesia.

Hikmatun, T. 2014. 'Eksperimen penggunaan filler tepung kulit pisang dalam pembuatan nugget tempe'. Jurusan Teknik Jasa Produksi, Fakultas Teknik, Universitas Negeri Semarang, Indonesia.

Hombing, H.F. 2016. 'Analisa kadar air pada Biskuit'. http://heplinfreslysihom bing.blogspit.co.id/2016/03/analisa-kadar-air-pada-biskuit.html. Di akses pada tanggal 29 Maret 2018 pukul 18.00 Wita. 
Kahara, D.G. 2016. 'Pengaruh Substitusi Tepung Kulit Pisang Raja Terhadap Kadar Serat Dan Daya Terima Cookies'. Fakultas Ilmu Kesehatan Universitas Muhammadiyah Surakarta.

Kisnawaty W.S dan Kurnia P. 2017. 'Pengaruh Subtitusi Tepung Biji Nangka Pada Pembuatan Cookies Ditinjau dari kekerasan Dan Daya Terima'. Universitas Muhammadiyah Surakarta.

Martunis, 2012. 'Pengaruh Suhu dan Lama Pengeringan Terhadap Kuantitas dan Kualitas Pati Kentang Varietas Granola'. Fakultas Pertanian, Universitas Syiah Kuala, Darussalam, Banda Aceh - 23111, Indonesia.

Santoso, A. 2011.'Serat Pangan (Dietary Fiber) Dan Manfaatnya Bagi Kesehatan'. Jurusan Teknologi Hasil Pertanian, Fakultas Teknologi Pertanian, Unwidha Klaten.

Setyaningsih, Dwi, Anton Apriyantono, dan Maya Puspita Sari. 2010. Analisis Sensori untuk Industri Pangan dan Argo. Bogor: IPB Press

Subandoro,B. R..H., Atmaka, W. 2013. 'Pemanfaatan Tepung Millet Kuning dan Tepung Ubi Jalar Kuning Sebagai Subtitusi Tepung Terigu dalam Pembuatan Cookies Terhadap Karakteristik Organoleptik dan Fisikokimia'. Jurnal Teknosains Pangan Vol 2 No 4.

Singh, C., Rias, S., Saxena, D.C. 2008, Eeffect Of Incorporating Sweetpotato Flour to Wheat Flour on Quality Chacteristics of Cookies. African J. Food Science, 2,6572 .

Wakano, D., Samson. E., Tetelepta D. L. 2016. 'Pemanfaatan Limbah Kulit Pisang Sebagai Bahan Olahan Kripik Dan Kue Donat Di Desa Batu Merah Kota Ambon'. Jurusan Biologi Fakultas Matematika dan Ilmu Pengetahuan Alam.

Yudha, L. F., Joni, K. 2015. 'Pengaruh Penambahan Tepung Kulit Pisang Terhadap Pertumbuhan Bakteri Lactobacillus casei pada Es Krim'. Malang: Universitas Brawijaya Malang. 